\title{
KÜLTÜRÜMÜZDE PSIKODRAMAYA VE EMPATIK ILETIŞIME YATKINLIK
}

\author{
Üstün DÖKMEN*
}

\section{OZET}

Ruh sağlı̆ı alanında kullandığımız yaklaşımların büyük kısmı batı kültürünün ürünüdür. Bu yaklaşımların, evrensel oldugunu ve her külturde aynen uygulanabıleceğını ılen sürenlerın yanı sıra, evrensel olmadığını, ancak çeşıttı uyarlamatarla farklı kultürlerde uygulanabıleceğıni belirtenler de vardır. Bu alandakı tartışmalara açıklık getirmek amacıyla, çeşıtı ruhsal tedavi/gelıştirme yaklaşım. Iarının kültürümüzle uygunluğunu incelemekte yarar vardır. Konuşmamızda, psıkodramaya ıışkın temel kavramların ve teknıklerın -örneğın spontanı̆ğın, yaratıcılığın, rol oynamanın, rol değiştırme. nın- geleneksel kültürümúzle ve bugünkü yaşam bıçımımızle ne ollçüde bağdaştı̆̆ı irdelenmektedır Edebıyat ve mınyatur gıbı geleneksel sanat ürünlerımızde ve gūnüumüzde gözledığımı kışlerarası ıletışım ơrüntủlerınde, spontanlığa, rol oynamaya ve ozelıkkle rol değıştırmeye (dolayısıyla empatı kurmaya) uygun dunya görusşlerı ve alışkanlıklar bulu. nup bulunmadığı incelenmektedır.

Elde edılen sonuçlara göre, geleneksel kültürümüzde, psıkodramanın temel kavramlarına/ ılkelerıne ve ozellıkle empatık letışıme yatkınlık vardır. Orneğın bazı masallarımızda empatı kurma- nın gereğı vurgulanmakta, dramatık kőylü oyunlarinda (seyırlik oyunlari) ise saptanan rol oyunlarına yer verımektedır. Ayrica Türkçe'de somut kavramların sayısı soyutlara oranla belırgın ólçide fazladır; đull, dusşünme ve yaşam bıçımı arasında karşııkI Iıı̧kı bulunduğunu dıkkate alırsak, kültüümüze ozgü olan bu dı ozelığının, psıkodrama ıçın uygun bır zemın hazırladığını ılenı surebılırız. Cüunkü, dıldekı somutlaştırma eğıımt, kışısel duyguları soyut kavramlarla sözel olarak anlatmak yerıne, dramatıze ederek anlatmaya yatkınlık sağlıyor olabıır ( $\mathbf{S} \gamma z$ konusu bu kültürel potansıyelden yararlanılarak, psıkodramada duygularını dramatıze etmekten kaçınan kışıler ıçın neler yapılabıleceğı araştırılabııır.) Geleneksel kültürümuzde, pstkodramaya ve empatık Iletışıme yơnelık belırlı bır yatkınlık bulunmasına karşilık, bazı ónemlı sorunlara da sahıbız Gerek geçmışte, gerekse günumuzde, insantarımızın spontanlıklarının ve bireyselikklerının bastırıması ve bastiriliyor olması-, bu alanda onemlı bir sorundur. Kendı elımızle spontanlığımızı bastırmamız, kültürümüzde mevcut olan dramatize etme potans!yelınt gölgelemektedir Bu potansıyelın gözle görujnür hale gelmesı ıçın neler yapılabıleceğını araşıırmak, psıkodrama oturumlarında karşılaşılan sorunlar ıçın, bir peşın çozum olabılır 